Економічні науки: збірник наукових праць Луиького національного технічного університету. Серія "Регіональна економіка". Випуск 17 (67). Редкол.: відп. ред. к.е.н., професор І.В. Кривов’язюк. Луцьк: ІВВ Луцького НТУ, 2020. 348 с.

УДК 630·6:502

Турицька М.M.,

аспірантка кафедри економіки і підприємництва, ДВНЗ «Ужгородський національний університет»

\title{
ЕКОЛОГО-ЕКОНОМІЧНА ЕФЕКТИВНІСТЬ ПРИРОДООХОРОННИХ ВИТРАТ ЛІСОВОЇ ГАЛУЗІ
}

В статті досліджено науково-теоретичну базу ефективності діяльності підприємств. На основі опрацьованих джерел розширено термін екологоекономічна ефективність діяльності суб'єктів господарювання, яка $\epsilon$ результатом ефективних управлінських рішень спрямованих на утримання балансу між економічними та екологічними показниками виробничої діяльності, врахуванням впливу на довкілля в майбутніх періодах виробничих циклів та витратами на природоохоронні заходи згідно стратегії розвитку підприємства.

Розглянуто питання економічної та екологічної ефективності природоохоронних заходів лісової галузі спрямованих на утримання балансу між економічною віддачею виробничих процесів та екологічним збитком. Досліджено природохоронні витрати лісової галузі та визначено їх екологоекономічну ефективність в майбутніх періодах. Доведено, що для забезпечення ефективного управління лісовою галуззю $\epsilon$ важливим дослідження методів оцінки ефективності природоохоронних заходів лісогосподарських підприємств, розробка нормативно методичних розрахунків екологічних збитків та антропогенного впливу на довкілля.

Досліджено принципи екологічної ефективності, що полягають у прагненні отримувати прибуток, але разом з цим знижувати вплив на довкілля i зменшувати використання природних ресурсів, цим самим підвищувати рентабельність лісової галузі.

Ключові слова: ефективність, еколого-економічна ефективність, природоохоронні витрати.

Turytska M.

\section{ECOLOGICAL AND ECONOMIC EFFICIENCY OF ENVIRONMENTAL COSTS OF THE FOREST INDUSTRY}

Efficiency is a guideline for the development of an enterprise, evidence of maintaining a dominant position in the market, and the correct use of its competitive advantages and resources. Therefore, the issue of enterprise performance management plays an important role in the formation of economic processes. For forestry enterprises that use exhaustive natural resources in their production activities, the issue of improving economic efficiency is acute. First of all the issue 
Економічні науки: збірник наукових праць Луиького національного технічного університету. Серія "Регіональна економіка". Випуск 17 (67). Редкол.: відп. ред. к.е.н., професор І.В. Кривов’язюк. Луцьк: ІВВ Луцького НТУ, 2020. 348 с.

of efficient use of forest resources and measures that increase their ecological and economic efficiency is of great ecological importance.

The article examines the scientific and theoretical basis of the efficiency of enterprises. Based on the processed sources, the term ecological and economic efficiency of business entities' activities is expanded, which is the result of effective management decisions aimed at maintaining a balance between economic and environmental indicators of production activity, taking into account the impact on the environment in future periods of production cycles and the cost of environmental measures according to the company's development strategy.

The issues of economic and environmental efficiency of environmental protection measures of the forest industry aimed at maintaining a balance between the economic impact of production processes and environmental damage are considered. The nature protection costs of the forest industry are studied and their ecological and economic efficiency in future periods is determined. It is proved that to ensure effective management of the forest industry it is important to study methods for assessing the effectiveness of environmental protection measures of forestry enterprises, develop regulatory and methodological calculations of environmental losses and anthropogenic impact on the environment.

The principles of environmental efficiency are studied, which consist in the desire to make a profit, but at the same time reduce the impact on the environment and reduce the use of natural resources, thereby increasing the profitability of the forest industry.

Key words: efficiency, environmental and economic efficiency, environmental costs.

\section{Турицкая M.M.}

\section{ЭКОЛОГО-ЭКОНОМИЧЕСКАЯ ЭФФЕКТИВНОСТЬ ПРИРОДООХРАННЫХ ЗАТРАТ ЛЕСНОЙ ОТРАСЛИ}

В статье исследованы научно-теоретическую базу эффективности деятельности предприятий. На основе обработанных источников расширен срок эколого-экономическая эффективность деятельности субъектов хозяйствования, является результатом эффективных управленческих решений направленных на удержание баланса между экономическими и экологическими показателями производственной деятельности, учетом влияния на окружающую среду в будущих периодах производственных циклов и расходами на природоохранные мероприятия согласно стратегии развития предприятия.

Рассмотрены вопросы экономической и экологической эффективности природоохранных мероприятий лесной отрасли направленных на удержание баланса между экономической отдачей производственных процессов и экологическим ущербом. Исследована природоохранных расходы лесной отрасли и определены их эколого-экономической эффективности в будущих 
Економічні науки: збірник наукових праць Луиького національного технічного університету. Серія "Регіональна економіка". Випуск 17 (67). Редкол.: відп. ред. к.е.н., професор І.В. Кривов'язюк. Луиьк: ІВВ Луцького НТУ, 2020. 348 с.

периодах. Доказано, что для обеспечения эффективного управления лесной отраслью является важным исследования методов оценки эффективности природоохранных мероприятий лесохозяйственных предприятий, разработка нормативно методических расчетов экологического ущерба и антропогенного воздействия на окружающую среду.

Исследованы принципы экологической эффективности, заключающиеся в стремлении получать прибыль, но вместе с этим снижать влияние на окружающую среду и уменьшать использование природных ресурсов, тем самым повышать рентабельность лесной отрасли.

Ключевые слова: эффективность, эколого-экономическая эффективность, природоохранные расходы.

Постановка проблеми. Економічний розвиток суспільства вимагає екологоорієнтованості виробничих процесів галузей, що використовують вичерпні природні ресурси. Вагомого екологічного значення набуває питання ефективності використання лісових ресурсів, заходів, що підвищують їх екологічну та економічну ефективність. Тому для забезпечення ефективного управління лісовою галуззю $\epsilon$ важливим дослідження методів оцінки ефективності природоохоронних заходів лісогосподарських підприємств, які відображають економічні, екологічні та соціальні моменти використання лісових ресурсів.

Аналіз досліджень i публікацій. Широкий спектр теоретичних узагальнень питання ефективності діяльності господарюючих суб'єктів представлений в роботах вітчизняних та зарубіжних вчених-економістів, таких як Ю.Сурмін, Л. Шваб, В. Осипов, Н. Каткова, С. Мочерний, М. Мейєр, П. Друкер, Б. Райзберг.

Категорія «ефективність» залишається однією 3 ключових в питаннях функціонування господарюючих суб'єктів, розвитку економічних систем та громадського суспільства ще з початку $\mathrm{XX}$ ст., проте, незважаючи на численність наукових підходів до трактування цього поняття, ще до кінця $\epsilon$ неповною класифікація видів ефективності та іï значення для промислових підприємств. У напрацюваннях дослідників недостатньо уваги приділяється питанню основних аспектів застосування методів 
Економічні науки: збірник наукових праць Луиького національного технічного університету. Серія "Регіональна економіка". Випуск 17 (67). Редкол.: відп. ред. к.е.н., професор І.В. Кривов'язюк. Луиьк: ІВВ Луцького НТУ, 2020. 348 с.

підвищення ефективності для екологоорієнтованих підприємств, якими $є$ підприємства лісового та мисливського господарства.

Основна мета. На основі досліджень удосконалити сутність та поняття «ефективність лісогосподарського комплексу», «економічна ефективність природоохоронних витрат лісогосподарського комплексу».

Виклад основного матеріалу. Проблеми ефективності господарюючих суб'єктів у рамках системного підходу в економіці розглядається багатьма науковцями, Так, Ю. Сурмін характеризує ефективність як показник успішності функціонування системи для досягнення встановлених цілей [9, с. 354]. Більше того, саме поняття ефективності притаманне виключно системам.

Ефективність діяльності господарюючого суб'єкта, як цілісної системи результативніший при умові дотримання умов його безперебійного функціонування, забезпеченню стійкості процесів роботи, зокрема поточної роботи та розвитку підприємства за рахунок його внутрішніх резервів. Досліджуване явище I. Гонтарєва [3] описує це явище як стан рівноваги, в яке економічна система здатна повертатися за рахунок внутрішніх резервів шляхом саморегулювання, називають стійким, або високорівневим станом економічної рівноваги. Воно характеризується балансом найважливіших макро- або/і мікроекономічних параметрів, таких як "попит пропозиція", "доходи - витрати ", "позикові - власні кошти", "обсяг виробництва - реалізація" і ін., що забезпечують їх оптимальне, тобто беззбиткове функціонування.

Детальне обгрунтування трактування, яке відображає походження поняття «ефективність» від поняття «ефект», яке у перекладі з латинської означає «результат». Л.І. Шваб, зазначає, ефект може бути як позитивним, коли зміни є корисними, так i негативним, коли зміни деструктивні, або нульовим, коли змін немає. Визначення ефективності діяльності господарючого субєкта полягає в оцінці його результатів. Під результатом взагалі розуміють остаточний результат (висновок), що завершує собою будь-який процес. Але сама по собі величина 
Економічні науки: збірник наукових праць Луиького національного технічного університету. Серія "Регіональна економіка". Випуск 17 (67). Редкол.: відп. ред. к.е.н., професор І.В. Кривов'язюк. Луиьк: ІВВ Луцького НТУ, 2020. 348 с.

цих результатів не дає змоги зробити висновок про ефективність чи неефективність роботи підприємства, оскільки невідомо якою ціною вони отримані. Діяльність підприємства буде нерезультативною, якщо вона не завершується виключно вигодою для підприємства [15].

Опираючись на напрацювання вчених Д. Крисанова, В. Парсяка, Н. Фарафонова, В. Геєця та В. Семиноженка $[5,8$, 12 , 2] можна умовно розділити складові ефективності: економічну, соціальну, екологічну, організаційну, управлінську, технічну, інноваційну тощо. При цьому кожна 3 складових ефективності має свою систему показників, критерії та одиниці вимірювання.

Раціональна екологічно нормативна оцінка виробництва полягає в збалансованому використанні природно-сировинних, матеріальних ресурсів у всіх сферах лісового господарства. Оскільки, негативні зміни ресурсного, природного потенціалу пропорційні економічним результатам діяльності господарюючих суб'єктів лісового сектору. Принцип екологічної ефективності полягає у прагненні отримувати прибуток, але разом 3 цим знижувати вплив на довкілля i зменшувати використання ресурсів, цим самим підвищувати рентабельність галузі.

Недоліком є нестабільна можливість точно вимірювати кількісний екологічний ефект, а отже, і порівнювати його 3 фінансовими результатами. На думку М. Кочерги, правильніше враховувати екологічний ефект або, навпаки, екологічний збиток як складову частину показників економічної ефективності будь якого виробництва і більш правомірніше окреслювати показники еколого-економічної ефективності $[4$, c. 31].

Економічна обгрунтованість екологічної ефективності на тлі не сформованого єдиного підходу до визначення іiі показників має відповідати одному простому правилу - темпи зростання екологічного ефекту мають бути вищими від темпів зростання витрат.

На думку А. Невєрова, еколого-економічну ефективність 
Економічні науки: збірник наукових праць Луиького національного технічного університету. Серія "Регіональна економіка". Випуск 17 (67). Редкол.: відп. ред. к.е.н., професор І.В. Кривов’язюк. Луцьк: ІВВ Луцького НТУ, 2020. 348 с.

(EE) на рівні регіону можна визначити за формулою [7, с. 134]:

$$
\mathrm{E}_{\mathrm{E}}=\mathrm{E}_{\mathrm{CB}}-\Pi_{\Pi} / \mathrm{K}^{*} \mathrm{E}_{\mathrm{H}}+\mathrm{C}(2),
$$

де ЕСВ - екологічна оцінка суспільного виробництва (продукція безвідходного або маловідходного виробництва), грн.;

ПП - продукція, вироблена 3 порушеннями екологічних норм (соціальний збиток від забруднення довкілля), грн.;

C - поточні витрати на охорону, відновлення та експлуатацію природних ресурсів, грн.;

ЕН - нормативний коефіцієнт еколого-економічної ефективності природокористування;

К - одноразові витрати на охорону, відновлення та експлуатацію природних ресурсів, грн.

Для природоохоронних заходів необхідно порівнювати екологічний ефект із витраченими на це коштами. У цілому екоефективність будь-яких заходів науковці визначають як співвідношення додатної вартості до отриманого збитку. У підсумку ефективність системи екологічного менеджменту визначається виходячи зі ступеня досягнення запланованих показників [14, с. 55].

Екологічну діяльність підприємства визначаємо за ступенем екологізації виробничих процесів, яка характеризується рівнем безвідходної (маловідходної) технології і $є$ основою сталого розвитку.

Визначення ефективності природоохоронних витрат на охорону довкілля здійснюється для контролю результативності заходів на різних рівнях господарювання (господарський комплекс, регіон, галузь, підприємство), що є необхідним для економічного обгрунтування та впровадження екологічних рішень [4, с. 32]. Водночас показник загальної економічної ефективності природоохоронних витрат окреслено В. Бобошком [1, с. 45], як співвідношення ефекту виробничо-економічної, еколого-економічної і соціально-економічної ефективності до 
Економічні науки: збірник наукових праць Луиького національного технічного університету. Серія "Регіональна економіка". Випуск 17 (67). Редкол.: відп. ред. к.е.н., професор І.В. Кривов'язюк. Луиьк: ІВВ Луцького НТУ, 2020. 348 с.

сумарних витрат, що були задіяні на реалізацію заходів. При цьому відмічений науковець зазначає, що «економічні результати разом з економічними показниками соціального ефекту $\epsilon$ повним економічним ефектом природоохоронних заходів. Однак на практиці важко визначити всі перелічені збитки та ефекти у вартісному вираженні», що робить метод недосконалим.

Сучасне визначення екологічної ефективності природоохоронних витрат повинно базуватися на нормативах спеціально розроблених для модельних підприємств лісової галузі. Нормативно-методичні розрахунки збитків та антропогенного впливу на довкілля є застарілими, оскільки сформовані ще в радянські часи для матеріально-технічної бази підприємств того часу. На цьому етапі доцільним $\epsilon$ використання зарубіжного досвіду 3 методики розрахунку норми природоохоронних витрат для збільшення екологічної ефективності виробничих процесів. Баланс між економічними i екологічними показниками ефективної діяльності підприємства може бути визначений тільки при вартісному виражені природоохоронних витрат.

Еколого-економічна оцінка ефективності діяльності виробничих процесів підприємств повинна визначати їх вплив на довкілля в майбутніх періодах і переводити у вартісний вимір показників для планування заходів та нормування виробництва, визначення рівня виконання природними ресурсами екологосоціальних функцій, здійснення розрахунку на природоохоронні витрати.

Фундаментальними напрацюваннями у сфері екологоекономічного розвитку підприємств є дослідження О. Врублевської, Є. Хлобистова, Л. Мельника, С. Мочерного, зокрема в лісовій галузі Ю. Туниці, І. Синякевича.

Основною функцією еколого-економічної оцінки, на думку Є. Хлобистова та М. Потабенко, є інформаційна, яка зумовлюється максимальною ймовірністю визначати, яким чином процеси, що відбуваються у природі, суспільстві i технічних системах, пов'язані 3 використання природних 
Економічні науки: збірник наукових праць Луиького національного технічного університету. Серія "Регіональна економіка". Випуск 17 (67). Редкол.: відп. ред. к.е.н., професор І.В. Кривов'язюк. Луиьк: ІВВ Луцького НТУ, 2020. 348 с.

ресурсів, і як останні впливають і визначають ефективність діяльності економічних суб'єктів. На основі екологоекономічної оцінки розраховують еколого-економічні ставки. У свою чергу, ставки впливають на формування екологоекономічних інструментів, покликаних регулювати використання природних ресурсів [13, с. 25]. Під екологоекономічною оцінкою Л. Мельник розуміє економічні показники, що характеризують зміну параметрів господарської діяльності підприємств (витрати, доходи та їхні зміни), як результат використання природних ресурсів або впливу на елементи довкілля [6].

Стосовно еколого-економічного ефекту висловився Ю. Туниця, який стверджує, що в його основі $\epsilon$ чистий економічний ефект виробничо-господарської діяльності за мінусом екологічних витрат і втрат. Відповідно, поняття "еколого-економічної ефективності" однаковою мірою відповідає законам розвитку суспільства і природи. Так, застосування критерію максимуму прибутку в економічній оцінці використання природних ресурсів вимагає введення екологічних обмежень [11, с. 18].

Отже, еколого-економічна ефективність діяльності суб'єктів господарювання $€$ результатом ефективних управлінських рішень спрямованих на утримання балансу між економічними та екологічними показниками виробничої діяльності, врахуванням впливу на довкілля в майбутніх періодах виробничих циклів та витратами на природоохоронні заходи згідно стратегії розвитку підприємства.

Алгоритм еколого-економічної оцінки зумовлюється багатоаспектністю, залежно від сфери чи виду економічної діяльності. Так, Є. Хлобистов розглядає поетапність зазначеної оцінки на прикладі функціонування лісогосподарської сфери, що базується передусім на [13, с. 27]:

- окресленні предмету оцінки природних ресурсів, що оцінюється (лісорослинна база, лісовий фонд, деревообробні підприємства, рекреаційні пункти); 
Економічні науки: збірник наукових праць Луиького національного технічного університету. Серія "Регіональна економіка". Випуск 17 (67). Редкол.: відп. ред. к.е.н., професор І.В. Кривов'язюк. Луиьк: ІВВ Луцького НТУ, 2020. 348 с.

- визначенні споживної вартості природних лісових ресурсів, функцій, способів користування, а також критеріїв їх оцінки;

- обгрунтуванні кола фактичних i потенційних споживачів лісосировинних природних ресурсів (галузей, сфер виробництва, підприємств, регіону, суспільства в цілому);

- параметричному і факторному аналізі стану природних ресурсів із застосуванням тих чи інших критеріїв виміру (натуральних, натурально-вартісних, вартісних) стану природних ресурсів залежно від особливостей впливу дестабілізуючих факторів.

Системою екологічного управління природними ресурсами, зокрема лісовими та водними, передбачено категорію економічного збитку завданого довкіллю, підконтрольній державі території внаслідок погіршення стану природних ресурсів, забруднення чи знищення.

Процес використання лісових ресурсів пов'язаний з їхнім виснаженням, у результаті чого підприємства лісової галузі беруть активну участь в їх охороні та відтворенні. А це підтверджує прямий взаємозв'язок лісогосподарської діяльності iз природоохоронною. Природоохоронною діяльністю підприємств лісового господарства у широкому розумінні пропонуємо вважати діяльність, що спрямована на досягнення максимального соціально-економічного ефекту від поліпшення стану лісових масивів, раціонального їх використання, комплексної переробки й збереження лісових ресурсів [10].

Сучасна лісова галузь при використанні наявної матеріально-технічної та лісосировинної бази має обмежені ресурси на екологічні цілі, саме тому є неможливим збільшити економічне зростання шляхом використання природних ресурсів, оскільки це передбачає екологічні збитки в майбутньому, а відповідно і матеріальні. Виходом з ситуації $є$ екологоорієнтоване ефективне управління лісовими ресурсами, що передбачає використання екологічного менеджменту, вирахування еколого-економічного та соціального ефекту від природоохороних заходів. 
Економічні науки: збірник наукових праць Луиького національного технічного університету. Серія "Регіональна економіка". Випуск 17 (67). Редкол.: відп. ред. к.е.н., професор І.В. Кривов’язюк. Луцьк: ІВВ Луцького НТУ, 2020. 348 с.

Висновки. Еколого-економічна ефективність від природоохоронних заходів є орієнтиром розвитку лісової галузі. Стимулом який визначає управлінські дії стосовно напрямів розвитку, визначення показників економічної, екологічної та соціальної ефективності задля прогресу діяльності суб'єктів лісогосподарювання. Таким чином, визначається дохід, рентабельність природоохоронних заходів та термін їх окупності.

\section{Список бібліографічного опису}

1. Бобошко В.И. Методологические основы оценки затрат и выгод при реализации приро доохранных мероприятий// Проблема теории и практики управления. 2009. № 2. С. 43-53.

2. Геєць В. М., Семиноженко В. П. Інноваційні перспективи України : монографія. Харків : Константа, 2006. 272 с.

3. Гонтарева И.В. Временные факторы системной эффективности деятельности предприятия // Труды Одесского политехнического университета. 2009. №1 (31). С. 216-221.

4. Кочерга М.М. Ефективність екологічного менеджменту в сільському господарстві/ Агросвіт. 2013.№6. С. 29-33.

5. Крисанов Д., Стешенко О. Результативність й ефективність діяльності підприємств: оцінювання та максимізація. Аграрний сектор. Економіст. № 7. 2012. С. 21-25.

6. Мельник Л.Г. Екологічна економіка: Підручник. Суми: ВТД «Університетська книга», 2003. С. 102-103.

7. Неверов А.В., Деревяго И.П. Устойчивое природополь зование: сущность, концепция, механизм реализации. Минск: БГТУ, 2005. 173 с.

8. Парсяк В.Н. Управління бізнес-процесами - інструмент підвищення ефективності організації// Актуальні проблеми економіки. 2011. № 7 (121). C. 131-137.

9. Сурмин Ю.П. Теория систем и системный анализ: Учеб. пособие. К.: МАУП, 2003. $368 \mathrm{c.}$

10. Особливості методики обліку поточних природохоронних витрат у лісовому господарстві / М.М. Танасієва, В.В. Бонарев // Ефективна економіка. - 2018. №11. C. 94.

11. Туниця Ю.Ю. Лісознавчі витоки еколого-економічного вчення: індуктивний підхід Лісівнича академія наук України // Наукові праці Лісівничої академії наук України : зб. наук. праць. - Львів : РВВ НЛТУ України. 2002. С. 11-21.

12. Фарафонова Н.В. Сутність і складові економічної ефективності господарської діяльності підприємств АПК // Актуальні проблеми економіки. 2011. № 10 (124). C. 176. 
Економічні науки: збірник наукових праць Луиького національного технічного університету. Серія "Регіональна економіка". Випуск 17 (67). Редкол.: відп. ред. к.е.н., професор І.В. Кривов’язюк. Луцьк: ІВВ Луцького НТУ, 2020. 348 с.

13. Хлобистов Є.В., Потабенко М.В. Еколого-економічна оцінка механізму контролю за викидами парникових газів// Механізм регулювання економіки. 2007. № 3. С. 23-29.

14. Царенко О.М. Економічний механізм управління агропромисловим виробництвом з урахуванням екологічного фактора// Економіка АПК. 1998. № 10. C. $53-58$.

15. Шваб Л.І. Економіка підприємства : навч. посібн. К. : Вид-во "Каравела", 2005. 568 с.

\section{References}

1. Boboshko V.I. Metodologicheskiye osnovy otsenki zatrat i vygod pri realizatsii priro dookhrannykh meropriyaty// Problema teorii i praktiki upravleniya. 2009. № 2. p. 43-53.

2. Heiiets V.M., Semynozhenko V.P. Innovatsiini perspektyvy Ukrainy: monohraphiia. Kharkiv: Konstanta, 2006. 272 p.

3. Gontareva I.V. Vremennye faktory sistemnoy effektivnosti deyatelnosti predpriyatiya // Trudy Odesskogo politekhnicheskogo universiteta. 2009. №1 (31). P. 216-221.

4. Kocherha M.M. Efektyvnist ekolohichnoho menedzhmentu v silskomu hospodarstvi / Агросвіт. 2013.No.6.P.29-33.

5. Krysanov D., Steshenko O. Resulntatuvnist I efktyvnist diialnosti pidpryiemstv: otsiniuvannia I maksymizatsiia. Ahrarnyi sektor. Ekonomist. № 7. 2012. C. 21-25.

6. Melnyk L.H. Ekolohichna ekonomika: Pidruchnyk. Sumy: VTD «Universytetska knyha», 2003. P. 102-103.

7. Neverov A.V., Dereviaho I.P. Ustoychivoye prirodopolzovaniye: sushchnost, kontseptsiya, mekhanizm realizatsii. Minsk: BGTU, 2005. 173 p.

8. Parsiak V.N. Upravlinnia biznes-procesamy - instrument pidvyshchennia efektyvnosti orhanizatsii // Aktualni problemy ekonomiky. 2011. No. 7 (121). P. 131-137.

9. Surmin Yu.P. Teoriya sistem i sistemny analiz: Ucheb. posobiye. K.: MAUP, 2003. 368 p.

10. Osoblyvosti metodyky obliku potocgnych pryrodoochoronnych vytrat $\mathrm{u}$ lisovomu hospodarstwi / M.M. Tanasiieva, V.V. Bondarev// Efektyvna ekonomika. 2018. №11. P. 94.

11. Tunytsia Yu.Yu. Lisoznavchi vytoky ekoloho-ekonomichnoho vcheniia: induktyvnyi pidhid. Lisivnycha akademiia nauk Ukrainy // naukovi pratsi Lisivnychoi akademii nauk Ukrainy: zbirnyk naukovych prats. - Lviv : RVV NTTU Ukrainy. 2002. P. 11-21.

12. Farafonova N.V. Sutnist I skladovi ekonomichnoii efektyvnosti hospoarskoii diialnosti pidptryiemsyv APK// Aktualni problem ekonomiky. 2011. No. 10 (124). P. 176. 
Економічні науки: збірник наукових праць Луиького начіонального технічного університету. Серія "Регіональна економіка". Випуск 17 (67). Редкол.: відп. ред. к.е.н., професор І.В. Кривов’язюк. Луцьк: ІВВ Луцького НТУ, 2020. 348 с.

13. Khobystov Ye.V., Potabenko M.V. Ekoloho-ekonomichna otsinka mehanizmu kontroliu za vykydamy parnykovych haziv // Mekhanizmy rehuliuvannia ekonomiky. 2007. No. 3. P. 23-29.

14. Tsarenko O.M. Ekonomichnyi mekhsnizm upravlinnia ahropromyslovym vyrobnytstvom $\mathrm{z}$ urakhuvanniam ekolohichnoho faktora // Ekonomika APK. 1998. No. 10. P. 53-58.

15. Shvab L.I. Ekonomika pidpryiemstva: navchlnyi posibnyk K.: Vydavnytstvo "Karavela", 2005. 568 p. 